\title{
The Aesthetics of Balloon View in Bleak House
}

\author{
Reema Raveendran Nair \\ School of Letters, Mahatma Gandhi University, Kerala. Email: reemarnair@gmail.com
}

Received May 14, 2017; Revised July 13, 2017; Accepted July 20, 2017; Published August 10, 2017.

\begin{abstract}
Social thinkers on space and place have reiterated that viewing a space/place from a high vantage point involves certain powers and pleasures. However, there are alternate ways in which the aerial views have been experienced and represented. This article argues that the bird's-eye-view of London in the opening chapter of Charles Dickens' Bleak House is an instance of such an alternate representation. While the maps and panoramas of the nineteenth century represented the city as legible and knowable, the hot-air-balloon ascent, a popular form of entertainment in Victorian London, presented the city as obscure and incomprehensible. This very aesthetic of obscurity and incomprehensibility embodied in the balloon view is incorporated in the famous bird's-eye-view of London in Dickens' Bleak House. How this obscurity of vision, which is the most defining experience of the city in the novel, extends to the theme of the novel, is also explored in this article.
\end{abstract}

Keywords: Bird's-Eye-View, Balloon View, Victorian London, Bleak House.

\section{Introduction}

Michel de Certeau (1984), in his seminal work on spatial practices, has maintained that there is a voyeuristic pleasure involved in seeing "Manhattan from the $110^{\text {th }}$ floor of the World Trade Centre" (p. 91). From such a height, the city is available as "a text that lies before one's eyes. It allows one to read it, to be a solar Eye, looking down like a god" (p. 92). A halo of knowledge also surrounds this voyeuristic pleasure as the viewer is provided a false reassurance of being able to know and read the city from this vantage point. The bird's-eye-view/aerial view thus participates in the production of the "fiction of knowledge" (p. 92). Situated in the spatial perspective of the god, the voyeur, and the author, the spectator/reader assumes a position of power which also grants him/her the privilege of knowledge which is never available to the walkers on the streets down below. From the "murky intertwining" (p. 93) streets at the ground level, one can never 'see' or 'read' space. The two different spatial perspectives or scales (the aerial and ground level) are explained by de Certeau as working in contrasting and opposing ways. While the bird's-eye-view partakes in producing narratives of vision, transparency, order and knowledge, the experience of space from ground level appears to elude legibility or clarity of vision (p. 93).

Though such a theorising of the aerial view holds sway over contemporary spatial and visual studies, there are alternate ways in which aerial views have been experienced and represented. The spatial perspective of the aerial view need not always be related to pleasure, power and knowledge. This article attempts to make a case for those alternate/other bird's-eyeviews that embody the experience and aesthetics of fear rather than pleasure, of partial vision rather than clarity, of obscurity rather than transparency, and of incoherence rather than

(c) AesthetixMS 2016. This Open Access article is published under a Creative Commons Attribution Non-Commercial 4.0 International License (http://creativecommons.org/licenses/by-nc/4.o/), which permits non-commercial re-use, distribution, and reproduction in any medium, provided the original work is properly cited. For citation use the DOI. For commercial re-use, please contact editor@rupkatha.com. 
knowledge. It takes Charles Dickens' effective employment of the bird's-eye-view of London in Bleak House (1853) as a case in point. The alternate accounts of the aerial views may include those related to obscurity in visual perception or otherwise to psychological fears like the fear of heights. (The fear of heights acrophobia and vertigo, interestingly, is related to the urban space, its increasing number of skyscrapers and high-rise buildings.) The obscurity of vision in the aerial view was perhaps experienced for the first time during the actual flights in the sky by means of hot air balloons. The passengers could not easily comprehend what they saw from such a height, as they had difficulties adjusting their vision with the sudden alteration in the scale of viewing (Thebaud-Sorger, 2013, p. 46-47). Such bird's -eye-views also sometimes found representation in contemporary fiction. The bird's-eye-view description of London in Dickens' Bleak House embodies the aesthetics of the balloon view; and therefore reflects obscurity, illegibility and incomprehensibility.

\section{The City from the Bird's-Eye-View}

Bird's-eye-views have played a prominent part in representing the city. It is one of the popular spatial perspectives that have pictured the space of the city since the Renaissance. During the Renaissance, the artists all over Europe had created bird's-eye-views of almost all major cities, some of which were later used as images to symbolize those cities. In these city views, the linear perspective, which was then a newly invented technique of representation, was used profusely by the artists. John Roman (2015) observes that during the Renaissance "every major city in Italy was illustrated in the now famous bird's-eye-views of cities; an art form that eventually spread throughout Europe in the High Renaissance and later to the rest of the world" (p. 43). These images by artists are considered to be the predecessors of maps or the early forms of maps. Sometimes, a bird's-eye-view image comprising the prominent buildings of the city was used to symbolise the city in official seals, medals and coins. For instance, Peter Barber (2012) has observed that the City Corporation continued to use the same seal containing the image of the walled city of London dominated by its churches and towers from 1190 to 1967 (p. 6). For centuries, this bird's-eye-view image of the old London symbolised the city. Thus in art and cartography, the aerial perspective was imagined much before it was possible to experience this view in actuality. As Michel de Certeau has observed, "the desire to see the city preceded the means of satisfying it. Medieval or Renaissance painters represented the city in a perspective that no eye had yet enjoyed" (p. 92). He has further remarked that this perspective provided by the painters, bestowed a celestial eye onto the spectators.

The bird's-eye-view of London was available to the Victorians in a variety of forms. This view was circulated among the general public in the form of panoramas, maps, views from St Paul's cathedral, views from actual flights in hot air balloons and the several descriptions and images of these flights (Nead, 200o). The maps themselves were of several kinds like the medical maps, poverty maps, Ordnance Survey maps and maps in guidebooks to the city. Though all of these were aerial views, each of them was practiced differently; and was part of different kinds of discourses related to the city. They also represented/produced the city differently. Therefore, these different aerial views cannot be reduced to one another. While the maps were associated with the production of knowledge about the city or for construction projects in the city, the balloon ascents were merely a form of popular entertainment. However accurate the nineteenth century maps, they were not a product of actual aerial observations or flights as the balloon views were. Therefore their perception, politics and aesthetics are very different. Consequently, there is a noticeable difference in the way the maps and balloon views have influenced the spatial 
imagination of contemporary fiction. Maps start gaining entry into the world of fiction from the latter half of the nineteenth century. Pictorial maps begin to be appended to the fictional works giving a map view of the setting of the novel. Sally Bushell (2015) has observed the key role played by maps in adventure fiction of the nineteenth century like R. L. Stevenson's Treasure Island (1883) and H. Rider Haggard's King Solomon's Mines (1885). These maps, even when they are part of fiction, carry "the underlying ideology of empire" (p. 612) that was a part of imperial mapping. Through these maps appended to popular forms of literature, "dominant ideology was mediated to the larger public" (p. 612).

The dominant ideology and forms of knowledge about the city were also circulated as maps in literatures related to urban social reform in Victorian London. These maps belong to that category of bird's-eye-view which may be related to pleasure, power and knowledge. De Certeau's analysis of the aerial view holds true in the case of maps. Maps, whether as part of imperialist strategies, or as socio-spatial reform projects of Victorian London, implied transparency, legibility and knowledge about the space/place represented. This nature and function of maps were retained in their fictional counterparts.

The balloon views, though also a bird's-eye-view like the map, were experienced and represented very differently; their aesthetics and politics were very different from those of the maps. The view from the balloon in the sky did not present the city as clearly and legibly as maps or panoramas did. The map making practices do not rely on actual aerial observations. The balloon ascent was a form of popular entertainment in Victorian London, which provided the people a momentary aerial panoramic view of the city. Written accounts of these ascents were also published (Nead, 200o). The history of cartography reveals how artistic and scientific techniques were used to make maps rather than any actual views from above. Maps belong to a separate tradition and category from those of actual flights or birds-eye-view observations. The actual view of the city from the balloon did not give any knowledge or clear visibility as those offered by the nineteenth century maps or panoramas. The balloon views had an aesthetic appeal rather than any functional value or purpose as those involved in maps. The purpose of their consumption or use by the people was not (unlike maps) to find out precise locations of places, or to acquire any knowledge about the city. Lynda Nead (2000), in her work on the images of Victorian London, contrasts the balloon views to other scientific maps of the city and observes that they mainly served as "a form of visual entertainment... no engineering projects can be planned from this map. Its driving force are aesthetics and narrative rather than pragmatism and accuracy of the Ordnance survey" (p. 22). Its purpose being aesthetic, or to present the city as a beautiful spectacle, they were also a part of night time entertainment when the gas-lit city streets, against the backdrop of the darkness of the night, produced a spectacular effect when seen from above.

\section{The Balloon View of London in Bleak House}

Dickens' Bleak House incorporates the bird's-eye-view of London as a part of its urban aesthetics. The opening chapter of the novel describes the city from the bird's-eye-view perspective. The view represents the city immersed in the November fog (a major air pollutant in Victorian London). The obscurity of vision caused by the fog is compared by Dickens to the lack of visibility experienced by the viewers up in the hot-air balloon. Though this comparison is only invoked in passing, it appears to sum up the entire birds-eye-view description in the novel. The influence of the balloon views on the bird's-eye-view can be discerned in the entire description. The obscurity, 
incomprehensibility and strangeness experienced by the balloon view is captured or embodied in the bird's-eye-view of London in Bleak House. Unlike de Certeau's aerial view, Dickens' view is not marked by the experience of any voyeuristic pleasure, power or transparency.

London... As much mud in the streets, as if the waters had but newly retired from the face of the earth, and it would not be wonderful to meet a Megalosaurus, forty feet long or so, waddling like an elephantine lizard up Holborn Hill. Smoke lowering down from chimneypots, making a soft black drizzle, with flakes of soot in it as big as full-grown snow-flakes gone into mourning, one might imagine, for the death of the sun. Dogs, undistinguishable in mire. Horses, scarcely better; splashed to their very blinkers...

Fog everywhere. Fog up the river, where it flows among green aits and meadows; fog down the river, where it rolls defiled among the tiers of shipping and the waterside pollutions of a great (and dirty) city. Fog on the Essex marshes, fog on the Kentish heights. Fog creeping into the cabooses of collier-brigs; fog lying out on the yards, and hovering in the rigging of great ships; fog drooping on the gunwales of barges and small boats. Fog in the eyes and throats of ancient Greenwich pensioners, wheezing by the firesides of their wards; fog in the stem and bowl of the afternoon pipe of the wrathful skipper, down in his close cabin;... Chance people on the bridges peeping over the parapets into a nether sky of fog, with fog all round them, as if they were up in a balloon, and hanging in the misty clouds. (p. 5)

The description captures the whole of the city in a single frame. It takes quick jumps from one location to another creating an impression of simultaneity. The sequentiality of narration is downplayed. The observation or gaze of the author-narrator reaches every part of the city presenting a totalizing view. Different identifiable, heterogeneous and distant locations are randomly mentioned, to generate the effect of viewing the city in its entirety; as if the whole scene is within the grasp of the author-narrator's gaze. The heterogeneous geographies of the city, the green aits (small islands in the river Thames), the meadows, the river, the bridge, the Essex marshes, the Kentish heights, are all brought together in a single glance. The fog is everywhere and so is the narrator's gaze. This view of the author-narrator is shared by the reader. According to Hillis Miller (1958), in this passage, "the spectator's place, as he shares the narrator's vision, is indefinite. He is, it seems, simultaneously everywhere in London and its environs, able to move instantaneously from the Essex marshes to the Kentish heights and anywhere in between" (p. 160). However, it may be noted that the gaze and the indefinite vision of the narrator are interfered at every instance by the fog. At every instance, vision is rendered obscure. Every attempt of the omniscient narrator to gaze through the fog amounts to failure. The omniscient narrator's 'gaze' is thus substituted by the aesthetics of the balloon 'view'. Unlike the term 'view', the term 'gaze' is associated with power.

The novels (and also other literary narratives) employ the bird's-eye-view in their narration because this vantage point gives the narrator (most often the third-person omniscient narrator) the convenience and the power to begin or pursue the narration (Warner, 2013). This vantage point was a significant part of literature from the classical times. For example, the bird'seye-view is found in literatures that are as old as the epics. Helen Lovatt (2013) observes that in the western epics, there are instances where gods take the form of birds to view the actions down below. Lovatt terms this birds-eye-view presented in the epics as "divine gaze"; this spatial perspective being the special privilege of gods:

The gods of epic gaze endlessly at the action: Zeus sits on Mount Ida, watches Hector and manipulates his mind (Iliad II.336-7), Athene perches in the form of a swallow in the rafters of Odysseus' palace, drinking in the slaughter below (Odyssey 22.240)... Mercury flies over 
the earth with the predatory gaze of a bird of prey, only to fall in love (Metamorphoses 2.708). (p. 29)

This is a very privileged vantage point as it gives the narrator power and control over her/his narration. This vantage point is most often related to the third person omniscient narrator. It is also indicative of the knowledge that the omniscient narrator possesses, and also the narrator's 'presence' everywhere. Therefore, this vantage point may be called the 'gaze' of the omniscient narrator. It is the vantage point from where the 'gaze' of the third-person omniscient narrator is best manifest. The narrator is positioned conveniently to take off or pursue her/his narration. The narrator, who needs to keep shifting locations, can also free herself/himself from the constraints of space. As Maria Warner (2013) has said, this vantage point gives the narrator "small, personal glimpses of private scenes, and so become a vehicle for gaining entry into secrets" (p. 11). It is further observed that this vantage point helps the character and the reader to be transported to another place. Flights have been used figuratively to stand for imagination. It implies both "flights of fancy on the one hand, and the rush of enhanced knowledgeenlightenment- on the other" (p. 11).In the Tales of Thousand and One Nights, the human characters are able to fly in the sky only by the power of magic which ultimately "grants the flyer superior powers - to see farther, to know and control more" (p. 11).

In Bleak House, the balloon view interferes with the omniscient gaze of the narrator creating obscurity in vision rather than giving the narrator any sort of privilege that is usually associated with the narrator's gaze. While the aesthetics and politics of 'gaze' are connected to power and knowledge, the balloon 'view' is related to obscurity and incomprehensibility. For the balloon viewers, the heterogeneity of the city gradually becomes incomprehensible as the balloon rises up; and the reverse happens when it comes down. The vision from above obscures the variety that the view of the city from below presents. This aspect differentiates the balloon view from street level views and also from other maps. The photographic and realistic image of the cityscape gets transformed into a hazy dreamlike vision in the balloon view.

In Dickens' narrative, the presence of dark pollutants in the air produces the same effect. All forms and shapes are made indistinct in the mud, mire, smoke and fog that cover the city and all life forms in it. "Dogs indistinguishable in mire. Horses scarcely better splashed to their very blinkers" (p. 5). Even the buildings are not clearly visible. The lack of visibility is also suggested by the presence of fog everywhere. Dickens, in the description, compares this blurring of vision to the experience of a balloon view when he says "people on the bridges...with fog all round them, as if they were up in a balloon, and hanging in the misty clouds" (p. 5). The lack of visibility caused by the fog is compared by Dickens to the lack of visibility that one experiences in a balloon view. Most of the balloon view descriptions of the nineteenth century highlight this blurring aspect as a singular experience of the balloon view. For example, the nineteenth century social investigator and reformer Henry Mayhew (1862) describes his experience of the balloon view thus:

I had seen the world of London below the surface, as it were, and I had a craving to contemplate it far above it- to behold the immense mass of avarice and cunning of noble aspirations and humble heroism blended into one immense black spot; to take as it were an angel's view of the whole city where perhaps there is more virtue and iniquity, more wealth and more want huddled together in one vast heap than in any other part of the earth; to look down upon ...palaces and workhouses...factory chimneys and church steeples...banks and prisons...to look down upon these as birds...and see the whole dwindle into a heap of rubbish... (p. 8-9) 
Hillis Miller compares Dickens' view of the city in the novel to an impressionistic painting. "The world which is revealed to this omnipresence is not, it seems, a world of multiplicity. Prior to any individual entities are the fog and mud. They are everywhere dissolving all solid forms like the shimmering atmosphere of an impressionist painting" (p. 160). The fog is everywhere and the mud "has drowned all distinct entities" (p. 161). According to Miller, Dickens' description, like the impressionistic painting, very successfully captures the experience of the urban environment. This bird's-eye-view, instead of making the city visible, hides the landscape and the people in it.

The balloon view, when practiced at night, presented the city as a spectacle of beauty, industrialisation and scientific progress. The beauty of the night time city, which is foregrounded in the balloon view, is replaced by the horrors of the darkness of the polluted city in the novel. In Dickens, the city becomes a spectacle not of beauty but of dirt, mud and fog. The darkness that results from the pollution, especially the fog, acts here as a substitute for the darkness of the night. The phrase "death of Sun" suggests a kind of permanence to this state of darkness. The city is taken back in time "and it would not be wonderful to meet a Megalosaurus, forty feet long or so, waddling like an elephantine lizard up Holborn Hill" (p. 5).

Obscurity, which is the defining experience of the city in the novel, also extends to the several threads in the plot of the novel. This is not to say that the novel considers as desirable such an experience. On the other hand, the plot of Bleak House develops on the logic of making visible what is hidden or kept a secret. There are several places which are seemingly unconnected; the mystery of the novel is unravelled as and when these connections and relations are made apparent. These houses are the several Bleak House(s) of the title. As Alice van Buren Kelley (1970) has observed, the title Bleak House "would include every form of gloomy housing to be found in the course of the story" (p. 253). Kelley then extends the metaphor of 'bleak house' to the state of Victorian England in general. "The society of Victorian England, then, is the bleak house which Dickens is intent on describing; and he builds his description with a series of physically and spiritually desolate houses..." (p. 254). It is this sense of totality which is conveyed in the balloon view of London in the first chapter. The cityscape, in its totality, is represented as bleak.

The High Court of Chancery, which is at the centre of this bird's-eye-view, is the very source and cause of bleakness of all the houses in the novel. "This is the Court of Chancery; which has its decaying houses and its blighted lands in every shire; which has its worn-out lunatic in every madhouse, and its dead in every churchyard..." (Dickens, p. 6). Dickens employs the aesthetics of the balloon view in his representation of the city because it suitably acts as a spatial trope that repeatedly manifests in the bleak atmosphere of the several houses/places in the novel; and it also functions as a dominant metaphor for the social issues that the novel is concerned about (the stagnant and archaic legal system, the increasing pollution and the spread of contagion in the city). Obscurity of vision is both literal and metaphorical. Ian Ousby (1975) observes that "difficulties of perception recur throughout Dickens' work" (p. 382). The bird's-eye-view of London from the roof of Todger's in Martin Chuzzlewit resembles the view of the city in the first chapter of Bleak House on the same account (p. 382). The "complex and crowded urban world... poses disquieting problems of perception. Rather than presenting itself to the eye in a passive and orderly manner it takes on a fractious and menacing life of its own" (p. 382). This difficulty of perception extends almost till the end of the novel. The characters in Bleak House, all in their own way, struggle "to understand this disordered environment- and these form perhaps the book's central theme" (p. 382). The characters grope around without being able to make sense of the fragments and partial views that are strewn around them. The "problems of perception" that Ousby refers to, may also be connected to the novel's commitment to voicing the necessity for 
urban reform. Pollution in the city and the spread of contagious diseases are some of the major social concerns of the novel which is again manifested as darkness and obscurity of vision. In the several 'dark' places in London (the slum Tom-All-Alone's, the pauper's graveyard, Krook's rags and bottle shop and the High Court of Chancery) are hidden not only the secrets of Lady Dedlock's past, but also the threat of disease and contagion that runs throughout the novel.

As observed earlier, the novel is keen on restoring transparency and legibility to this urban space. The novel seems to bestow great faith on the character of Inspector Bucket to render the city legible. The text bestows on Inspector Bucket the ability to perceive clearly and also share it with the readers towards the end of the novel. Bucket's vision is far superior to that of the omniscient narrator. Towards the end, when almost all the secrets are revealed and mysteries solved, London is described once again from the bid's-eye-view. This time the view is pictured in the mind's eye of Inspector Bucket and has no trace of any obscurity. "There, he mounts a high tower in his mind, and looks out far and wide. Many solitary figures he perceives, creeping through the streets; many solitary figures out on heaths, and roads, and lying under haystacks" (Dickens, p. 673). Bleak House is written from two narrative points of view; one is that of the third person omniscient narrator, and the other is from the point of view of the character Esther Summerson. Both the bird's-eye-views occur in the chapters written from the omniscient narrator's point of view. The omniscient narrator, who was denied clear vision in the bird's-eyeview description of the first chapter, reclaims it through Inspector Bucket. It is as if Bucket takes the place of the omniscient narrator; and this guarantees him the privilege of power and knowledge. The transformation from the balloon 'view' (of the opening chapter) to the narrator's 'gaze'(materialised through Inspector Bucket), is what Bleak House desires to achieve through its entire narrative which joins in voicing the need for urban social reform. However, the irony is that, it is the bird's-eye-view of London in the opening chapter of Bleak House which is acknowledged as one of the most memorable bird's-eye-views of London in literature so far.

It was not uncommon in the Victorian age to represent the city in exaggerated and melodramatic terms. The French illustrator Gustave Dore's images of London, which occupies a prominent presence in many of the histories of nineteenth century London, is an example of such a practice of representing the modern city. The balloon view of London in Bleak House also borders on excess. In the preface to the novel, Dickens states that he has "purposely dwelt upon the romantic side of familiar things" (p. 4). Perhaps, Dickens found the mode of romance or fantasy as essential in addressing anxieties related to urban life. Alan Pritchard (1991) terms the mode of 'romance' adopted in Bleak House as 'Gothic romance'. This novel is an important text in the Gothic tradition because it is one of the earliest representatives of the urban Gothic novels that had as its subject "the great modern city and its horrors" (433).

\section{References}

Barber, Peter. (2012). London: A History in Maps. London: The London Topographical Society and the British Library.

Bushell, Sally. (Summer, 2015). Mapping Victorian Adventure Fiction: Silences, Doublings and the Ur-Map in Treasure Island and King Solomon's Mines. Victorian Studies, 57(4), 611-637.

De Certeau, Michel. (1984). Walking in the City. The Practice of Everyday Life (91-110). (Steven Rendall, Trans.). Berkeley, Los Angeles and London: University of California Press.

Dickens, Charles (1853/1977). Bleak House. George Ford and Sylvere Monod (Eds.) New York: Norton. 
Dore, Gustave and Blanchard Jerrold. (1872/2005). London: A Pilgrimage. New York and London: Anthem.

Kelley, Alice van Buren. (December 1970). The Bleak Houses of Bleak House. Nineteenth-Century Fiction, 25(3), 253-268.

Lovatt, Helen. (2013). The Divine Gaze. The Epic Gaze: Vision, Gender and Narrative in Ancient Epic (29-76). Cambridge: Cambridge University Press.

Mayhew, Henry. (1862). A Balloon View of London. The Criminal Prisons of London and Scenes of Prison Life (7-10). London: Griffin Bohn and Company.

Miller, Hillis. (1958). Bleak House. Charles Dickens: The World of his Novels (160-224). Cambridge, Massachusetts: Harvard University Press.

Nead, Lynda. (200o).Victorian Babylon: People, Streets and Images in Nineteenth Century London. New Haven and London: Yale University Press.

Ousby, Ian. (1975, March). The Broken Glass: Vision and Comprehension in Bleak House. Nineteenth Century Fiction, 29(4), 381-392.

Pritchard, Allan. (March 1991). The Urban Gothic of Bleak House. Nineteenth-Century Literature, 45(4), 432452.

Roman, John. (2015). Birds-Eye-View Maps. The Art of Illustrated Maps: A Complete Guide to Creative Mapmaking's History, Process and Inspiration (43-46). Ohio: How Books.

Thebaud-Sorger, Marie. (2013). Thomas Baldwin's Airopaidia or the Aerial View in Colour. In Mark Dorrian and Frederic Ponsin (Eds.), Seeing From Above: The Aerial View in Visual Culture (46-65). New York: I. B. Tauris.

Warner, Marina. (2013). Intimate Communiques: Melchior Lorck's Flying Tortoise. In Mark Dorrian and Frederic Ponsin (Eds.), Seeing From Above: The Aerial View in Visual Culture (11-25). New York: I. B. Tauris.

Reema Raveendran Nair is pursuing her PhD in English at the School of Letters, Mahatma Gandhi University, Kottayam, Kerala. Her major research interests include Spatiality Studies, Victorian London and the Victorian Gothic Fiction. Email: reemarnair@gmail.com 